Sains Malaysiana 50(7)(2021): 2095-2107

http://doi.org/10.17576/jsm-2021-5007-23

\title{
Data Envelopment Analysis and Panel Regression in Analysing Technical Efficiency and Its Determinants of the Palm Oil Products-Based Manufacturing Subsector
}

(Analisis Penyampulan Data dan Regresi Panel dalam Menganalisis Kecekapan Teknik dan Penentu bagi Subsektor Pembuatan Berasaskan Produk Sawit)

NOORASIAH SULAIMAN* \& RAHMAH ISMAIL

ABSTRACT

This study measures the technical efficiency score of the manufacturing sector of the palm oil products-based subsector in Malaysia and investigates the major determinants that influence efficiency. Based on the Industrial Manufacturing Survey, this study explores the data from 2000 to 2015 over sixteen years, with a total of eleven subsectors of palm oil products-based. The first stage of the study is carried out with a data envelopment analysis (DEA) to calculate the technical efficiency score, which is considered a dependent variable. The second stage of the study uses a panel regression model to examine the determinants of efficiency comprise the variable capital-labour ratio, research and development, information communication technology, training, and skilled labour. The study findings show that most of the palm oil products-based subsectors are not operating efficiently. Skilled labour, technical and supervisory, and professional is one of the main determinants contributing to the efficiency level. The variable capital-labour ratio though significant, but harms the efficiency level. The moderating effects show that skilled technical and supervisory workers relatively affect the food industry's efficiency larger than the non-food industry. Therefore, the industry still has room to improve efficiency by utilising input efficiently. Moreover, the efforts involve organisational management, equipped appropriate technology and related factors that will improve efficiency, increase productivity and competitiveness of palm oil products-based industries.

Keywords: Data Envelopment Analysis; determinants of efficiency; palm oil products-based manufacturing subsector; panel regression; technical efficiency

\section{ABSTRAK}

Kajian ini mengukur skor kecekapan teknik industri pembuatan berasaskan produk minyak sawit di Malaysia dan mengkaji penentu penting yang mempengaruhi tahap kecekapan tersebut. Berasaskan data Banci Industri Pembuatan, kajian ini meliputi tempoh enam belas tahun dari 2000 hingga 2015, melibatkan sebelas subsektor pembuatan berasaskan produk minyak sawit. Tahap pertama kajian menggunakan Analisis Penyampulan Data (DEA) bagi mengukur tahap kecekapan teknik. Skor kecekapan digunakan sebagai pemboleh ubah sandaran. Tahap kedua analisis menggunakan model regresi panel mengkaji faktor penentu bagi kecekapan, meliputi pemboleh ubah nisbah modal-buruh, penyelidikan dan pembangunan, teknologi maklumat dan komunikasi, latihan dan tenaga buruh mahir. Keputusan kajian menunjukkan sebahagian besar subsektor pembuatan berasaskan produk minyak sawit tidak beroperasi pada tahap cekap. Tenaga kerja mahir, iaitu teknikal dan penyeliaan dan profesional adalah penentu penting yang menyumbang kepada kecekapan. Pemboleh ubah nisbah modal-buruh walaupun signifikan, namun mempengaruhi tahap kecekapan secara negatif. Keputusan bagi kesan moderasi menunjukkan pekerja mahir teknikal dan penyeliaan secara relatif mempengaruhi tahap kecekapan industri makanan berasaskan produk minyak sawit adalah lebih besar daripada industri bukan makanan. Oleh itu, industri mempunyai potensi besar dalam meningkatkan tahap kecekapan dengan mengguna input dengan lebih efisien. Tambahan lagi, usaha tersebut melibatkan pelbagai aspek termasuk pengurusan organisasi, mengguna teknologi sesuai dan seumpamanya demi meningkatkan kecekapan, produktiviti dan daya saing industri berasaskan produk minyak sawit.

Kata kunci: Analisis Penyampulan Data; kecekapan teknik; penentu kecekapan; regressi panel; subsektor pembuatan berasaskan produk minyak sawit 


\section{INTRODUCTION}

Productivity and efficiency are essential sources of competition in the global market (European Commission 2009). On a broader concept, competition deals with the firm's ability to enhance product quality, incorporate attractive features, improve product technology (Latruffe 2010), use input factors and human capital, and increase its performance to enhance overall productivity (Porter 1990). Consequently, in a highly competitive world, examining efficiency and determinants of efficiency is prominent and increases the business's competitiveness. Finally, firms must prosper both in domestic and international markets to assure profits.

The contribution of the palm oil products-based manufacturing subsector is undeniably vital to Malaysia's economic performance, and progressively, to vegetable oils entering the food supply chain. As one of the world's largest palm oil exporters, Malaysia currently accounts for $30 \%$ of world palm oil production and $32.6 \%$ (USD9.0 billion) of global palm oil exports in 2016 (MPIC 2017). As one of the largest producers and exporters of palm oil and palm oil products, Malaysia has efficiently met the rising global demand for oils and fats. Exports of palm oil and palm-based products in RM67,583 million contributed approximately $8.70 \%$ of total manufacturing exports (MPOB 2017).

The increasing global demand for palm oil products and widely traded edible oil and fats has resulted in a huge increase in global consumption of palm oil over the last two decades. Global palm oil consumption rose from $33.4 \%$ to $35.7 \%$ for $2015-2016$ and $2019-2020$. However, the increase gained competition from soybean oil, which accounted for $30.0 \%$ of global consumption and placed the second largest consumption of edible oils and fats (Shahbandeh 2020). Moreover, the Malaysian palm oil industry is continuously confronted with competition from other vegetable oils, particularly soybean oil. The challenge is that most of the oils are inter-substitutable and thus in competition with each other. Research by Amiruddin et al. (2005) described a short-and longterm relationship between edible oil prices since oils were in close competition with each other and formed a bi-directional causality between oils. In another study, the disparity between palm oil and soybean oil prices significantly affected the long-term demand for palm oil in China (Zakaria et al. 2017).

Palm oil is a regular oil in consumer products and processed foods. Though the global production and consumption of palm oil (in terms of volume) rise steadily over the last several years, it is affected by price movements in related oils as they compete for a global vegetable oil market (MPOB 2020). Another problem concerns consumers with regard to the production of soybeans derived from genetically modified seeds, which may change the market for palm oils and fats. Environmental issues are also rising, particularly concerning the potential relation between deforestation and the increase in palm oil production, depending on replanting activities and accompanying improvement in yield, i.e. efficiency and productivity.

Previous works on the technical efficiency of Malaysia's manufacturing sector are carried out by many researchers (Ismail \& Sulaiman 2007; Jajri \& Ismail 2006; Mahadevan 2001; Mohd Noor \& Ismail 2007). However, some recent technical efficiency studies have paid special attention to the selected subsector of the manufacturing sector, such as the transport and rubber manufacturing industries (Fahmy et al. 2020, 2017). Few studies on the technical efficiency of the food manufacturing industry have also been performed in Malaysia. In initial research, however, Kalirajan and Tse (1989) only estimates the level of technical efficiency. A related study by Ismail (2009), Mad Nasir et al. (2013) and Yodfiatfinda et al. (2012) focused on large and small-medium-sized enterprises (SMEs). This research fills the gap in current literature, concentrating on the efficiency and determinants of the palm oil products-based manufacturing subsector by classifying them into the food and non-food industry.

This study delineates two significant contributions to the existing literature. Firstly, by classifying the palm oil-based manufacturing industry into two categories, this study contributes to the current literature on the technical efficiency of food and non-food palm oil-based industries. Hence, studying food and non-food palm oil productsbased industries provides a more useful insight for this study. Secondly, by considering various determinants of efficiency, particularly human capital by labour types, this study provides a better understanding of skilled labour workforce contribution.

Based on the issues discussed, efficiency remains an essential aspect of assessing the industry's performance. This research, therefore, pursues two objectives. The first objective was to evaluate the efficiency's score. The second objective was to analyse the efficiency determinants to understand the competitiveness of the palm oil productbased manufacturing industry. Determinants comprise human capital, capital intensities, training, information communication technology (ICT), and research and development expenditure. 
The remainder of this paper is unfolding as follows. The next section explains the approach used, the data sources, and defines variables, and specifications of the model. Subsequent section provides results and discussions, and finally, last section reserves for a conclusion.

\section{DATA AND METHODS}

This study uses data from the Malaysian Department of Statistics (DoSM 2013) obtained through the Industrial Manufacturing Survey. The data sets that combine time series and cross-sections covering sixteen years of data from 2000 to 2015 are divided into eleven subsectors of industry into 5-digit level of the Malaysian Standard Industrial Classifications (MSIC 2008) with a total of 176 observations. This study applies two stages of analysis. The first stage estimates the technical efficiency of the subsectors using the data envelopment analysis (DEA) method. The second stage of the panel data set analysis deals with panel regression to continue examining efficiency determinants of the palm oil products-based manufacturing subsector.

\section{VARIABLES AND INDUSTRY DESCRIPTION}

Prior studies on the determinants of technical efficiency have observed different factors. Factors such as training, technology, skilled worker, ICT, research and development, and firm size are observed (Coelli \& Battese 1996; Fahmy et al. 2020, 2019, 2017; Ismail \& Sulaiman 2007; Sulaiman \& Ismail 2007). In support of previous research, this study considers that these variables are expected to make a significant contribution to efficiency performance. Thus, by considering the relevant variables as a determinant of technical efficiency, this study would provide a better explanation of the technical efficiency and contribution of each variable in the palm oil-based products industry.

The variables examined in this analysis were the capital-labour ratio, the expenditure of training, spending on research and development, spending on information and communications technology (ICT), and skilled labour. According to the Malaysia Standard Classification of Occupations (MASCO 2013), highly qualified employees categorised by occupational category include managers, professional, and technical and associates professionals. Gross output, capital values, training, research and development, and ICT expenditure are calculated in the Malaysian ringgit currency. Lastly, using the base year 2000, the producer price index (PPI) was used to deflate variables.

In computing the technical efficiency scores, this study utilises output and input variable data. The output variable $\left(y_{1}\right)$ is the total value of the gross industrial output, which refers to the value of sales, while input variables comprise the number of full-time labour $\left(x_{1}\right)$, and the value of physical capital $\left(x_{2}\right)$. In this study, capital refers to the machine and technology used in that particular subsector, which used palm oil as an input source.

As a focus on the manufacturing subsector palm oil products-based, selecting subsector on the basis of the palm oil inputs used in the manufacturing products. The inputs comprise palm oil and fats, crude palm oil, refined palm oil, palm kernel oil, and palm oil active substances. The subsectors are classified at the 5-digit level of Malaysian Standard Industrial Classification (MSIC). The descriptions of the industry analysed in this study are in line with the MSIC 2000 and MSIC 2008 (Appendix 1). Furthermore, this study classified the subsector into the food and non-food industry. Out of the eleven subsectors, six subsectors are categorised into the food industry, while the remaining five subsectors are grouped under the non-food industry. As shown in Appendix 1, the food industry ranges from 1 to 6 , and the non-food industry ranges from 7 to 11 .

\section{DATA ENVELOPMENT ANALYSIS}

The Data Envelopment Analysis (DEA) is used in the first stage of the analysis, i.e., the technical efficiency of the palm oil-based products subsector. The DEA approach is a linear programming technique used to test the firm's decision-making unit (DMU). Therefore, the method has permitted the conversion of multiple inputs and outputs into a scalar measure of efficiency and is extensively used in economics and operational research (Seiford 1996). The system was developed by Farrell (1957), who estimated the boundaries of the firm's output or production and was further explored by Charnes et al. (1978), and Coelli (1996) analyses technical efficiency through the DEA program.

The method, therefore, assumes that there are $N$ firms that produced Q output through $\mathrm{K}$ inputs to understand the exact approach of multiple inputs and outputs, which are often reduced to single virtual inputs and outputs, within the standard non-parametric approach (Coelli et al. 2005). A similar argument is used for output minimised input subjects. In this case, given the actual amount of inputs used by $n$th firm, the maximum potential 
output should be greater than or equal to the amount produced by the $n$th firm.

The first approach to DEA consisted of the Charnes, Cooper, and Rhodes (CCR) model used an input assuming that the output produced at a constant return to scale(CRS) (Charnes et al. 1978). Under the model, efficiency is associated with an increase in inputs to an equivalent rise in output. Consequently, CRS occurred when an increasing number of inputs resulted in an equal increase in outputs. The CCR-CRS model is a linear relationship between input and output. In the ratio form of the DEA model, the solution for each DMU, $j$ can be expressed as:

$$
\begin{aligned}
\text { Maximise } & \frac{\mathrm{u}^{\mathrm{T}} \mathrm{y}_{\mathrm{i}}}{\mathrm{v}^{\mathrm{T}} \mathrm{x}_{\mathrm{i}}} \\
\text { s.t. } & \frac{\mathrm{u}^{\mathrm{T}} \mathrm{y}_{\mathrm{i}}}{\mathrm{v}^{\mathrm{T}} \mathrm{x}_{\mathrm{i}}} \leq 1 \quad(\forall i)
\end{aligned}
$$$$
\mathrm{u}, \mathrm{v} \geq 0
$$

In equation (1), for each DMU $i$, the model obtains a vector $\mathrm{v}$ of input weights and a vector $\mathrm{u}$ of output weights, such that the weighted ratio of outputs and inputs is maximised. Where $\mathrm{u}$ and $\mathrm{v}$ are variable vectors, while $x_{i}$ and $y_{i}$ are respective parameters of input and output vectors for DMU $i$. In other words, the model gains the values for the weight vectors $u$ and $v$, in such a way that the efficiency calculation for this DMU $i$ is maximised. For example, if $\left(\mathrm{u}^{*}, \mathrm{v}^{*}\right)$ is a solution, then $\left(\alpha . \mathrm{u}^{*}, \alpha . \mathrm{v}^{*}\right)$ is also a solution. As a consequence, there are infinitely many solutions. As shown in (2), the solution procedures are maximised subject to the added constraints of $\mathrm{v}^{\mathrm{T}} \mathrm{x}_{\mathrm{i}}=1$. Thus, the model can be rewritten as in (2). The equation has been transformed from the ratio form in (1) to the multiplier form of the DEA model. In this case, the variables $u$ and $\mathrm{v}$ are replaced by the variables $v$ and $\mu$ respectively, to distinguish between these two models.

$$
\begin{aligned}
& \text { Maximise } \mu^{T} y_{i} \\
& \text { s.t } v^{T} x_{i}=1, \\
& \mu^{T} y_{i}-v^{T} x_{i} \leq 0, \quad(\forall i) \\
& \mu, v \geq 0
\end{aligned}
$$

As the CCR-CRS model of DEA is an input-oriented approach, from the multiplier form of the DEA model, we have established the dual form of the multiplier model, which is the envelopment of the DEA model. In this case, the $1+\mathrm{N}$ constraint is greater than the $\mathrm{K}+\mathrm{M}$ constraint. The envelopment form, as shown in (3) shows the value of $\theta$, which indicates the efficiency score for DMU $j(\theta \leq 0)$, which highlights the projection of the inefficient DMUs.

$$
\begin{array}{cl}
\text { Minimise } \theta & \\
\text { s.t. } \quad-y_{i}+Y \lambda \geq 0 & \text { output slack } \\
\theta x_{i}-X \lambda \geq 0 & \text { input slack } \\
\lambda \geq 0 &
\end{array}
$$

However, the inefficient DMUs to the optimum level, i.e. the firm is efficient is questionable, since its input can be reduced without changing the output. This position is identified as input slack. Similarly, the projection can also be output slack, which has been described as mixing inefficiency. From equation (3), the $-y_{i}+Y \lambda$ indicates the output slack and the $\theta x_{i}-X \lambda$ denotes the input slack.

In a later study, Banker, Charnes and Coopers (BCC) model took into account the variable return to scale (VRS) of a frontier used in the DEA model (Banker et al. 1984). The BCC-VRS model is more reliable and has an advantage over the DEA approach. First, the model calculates a variety of input and output variables. Second, the assumption of a functional relationship between input variables and output variables in a single study is not required. Third, the input and output variables have a different set of measurements. The definition of efficiency under the VRS is synonymous with an increase or decrease in input or outputs. It does not result in a proportional change in the outputs or inputs, respectively (Cooper et al. 2011).

Based on these arguments, this study employs the BCC-VRS model, which is considered increasing, constant, and decreasing returns to scale when working on the DEA programme (Coelli et al. 2005). The model suggests that the VRS assumption is more realistic as this study may involve a firm operating based on its scale efficiency. Besides, the DEA model only takes into account the convex combination, where $\left(\sum_{i} \lambda_{i}=1\right)$ shows the inputs and outputs of observed DMUs and DMUs are only benchmarked against similar size DMUs. In contrast, CRS may not be realistic by putting an input equal to the output.

This study occupies the output-oriented of BCC-VRS model, which assumes that each industry maximises the 
potential increase in outputs, holding inputs constant as presented in (4).

$$
\begin{array}{rll}
\text { Maximise } \theta & \\
\text { s.t. }-\theta y_{i}+Y \lambda \geq 0 & \text { output slack } \\
x_{i}-X \lambda \geq 0 & \text { input slack } \\
1^{T} \lambda \geq=1 & \\
\lambda \geq 0 &
\end{array}
$$

where the technical efficiency $\operatorname{score}(\theta)$ shows a proportional increase in output that can be achieved with inputs held constant.

\section{MODEL SPECIFICATION}

The second stage of the panel regression analysis involves the pooled least squares (PLS), the fixed effect and the random effect model. Finally, this study conducts a hypothesis test under the panel regression analysis to evaluate the best estimator of the models, as indicated above. Thus, this study undertakes two hypotheses: a pooled and fixed-effect model, and a second, a random and fixed-effect model.

The first hypothesis, the F-Wald test, is to perform the selection between the PLS and the fixed effect model, respectively, represented by the null hypothesis $\left(H_{0}\right)$ and the alternative hypothesis $\left(H_{1}\right)$. Referring to the rule of thumb, if the $(p<0.05)$, the null hypothesis is rejected, meaning that the fixed effect model is the best estimator to be chosen. Furthermore, the second hypothesis is carried out through the Hausman test to select the fixed-effects and the random effect model. In this case, $H_{0}: \alpha_{i}=X_{i,}, Z_{i}$; $H_{1}: \alpha_{i} \neq X_{i t}, Z_{i}$, where $H_{0}$ is a random effect and $H_{1}$ is a fixed-effect model (Greene 2008). The null hypothesis is dismissed if the $p$ value is significant $(p<0.05)$, suggesting that the fixed effect is the better estimator model.

The general model of the panel regression is expressed in the form of (5):

$$
Y_{i t}=X_{i t} \beta+\alpha_{i}+\mu_{i t} \quad(5) \quad t=1, \ldots, T ; i=1, \ldots, N
$$

where $Y_{i t}$ is the dependent variable observed for individual $i$ at time t. $X_{i t}$ is the time variant $1 \times k$ (number of independent variables) of the regressor vector. $\beta$ is the $k \times 1$ matrix of parameters. $\alpha_{i}$ is the unobserved time-invariant individual effect (for individual factors or cross-sections), $\mu_{i t}$ is an error term. However, since $\alpha_{i}$ is not observable, so that, the fixed effect model allows $\alpha$ to be correlated with the regressor matrix $X_{i t}$.

At this stage, this study is developing two models, Model I and Model II. Model I determines the effect of all independent variables influencing the level of technical efficiency. Also, with similar variables, model II highlights the interaction of a dummy variable defining between the food and non-food groups of industry focused on palm oil-based products by skilled employees in the occupational group. However, since $\alpha_{i}$ is constant $\left(\bar{\alpha}_{i}=\right.$ $\alpha_{i}$ ) the effect of $\alpha_{i}$ on the regressor is eliminated. The following equation, i.e. (6) and (7), outline the model defined in this study as models I and II.

$$
\begin{aligned}
T E_{i t} & =\alpha_{i}+\beta_{1} K L_{i t}+\beta_{2} P R O_{i t}+\beta_{3} T E C_{i t} \\
& +\beta_{4} \operatorname{lnICT}_{i t}+\beta_{5} \operatorname{lnTRN} N_{i t}+\beta_{6} \ln R N D_{i t}+\mu_{i t} \\
T E_{i t} & =\alpha_{i}+D_{1}+\beta_{1} K L_{i t}+\beta_{2} P R O_{i t}+\beta_{3} T E C_{i t} \\
& +D_{1} * \beta_{7} P R O+D_{1} * \beta_{8} T E C+\mu_{i t}
\end{aligned}
$$

Model I displays the importance of the technical efficiency measured for the subsector based on (4) of the first stage of the analysis. Next, i refer to subsector $i=1$, $\ldots, n$, and $t$ is the time or a particular year of subsector $i . \alpha_{1}$ is the intercept value of the subsector $i$. KL is the capitallabour ratio, TRN is the expenditure on training, RND is the expenditure on research and development, ICT is the expenditure on ICT information and communication technology, PRO is a professional worker, TEC is a technical and supervisory worker. At the same time, $*$ is the term of interaction, and $\mu$ is the term of error. Both types of labour are the proportion of total labour. The variables KL, TRN, ICT, and RND are logarithmic.

As model I, model II proposes an interaction term to further examine the effect of moderation between human capital variables and industry types on technical efficiency. The variable of skilled labour (professional and technical and supervisory workers) has interacted with the dummy variable $(D)$, labelled as 1 for the food industry and 0 for the non-food industry.

Next, Table 1 exhibits descriptive statistics of the variables used in this analysis. The table shows the mean, median, minimum and maximum values, and the standard deviation of all determinants. The variables used in this study show an acceptable rate for mean, minimum, maximum, and standard deviation values. 
TABLE 1. Descriptive statistics of determinant variables

\begin{tabular}{lcccccc}
\hline & KL & PRO & TEC & ICT & TRN & RND \\
\cline { 2 - 6 } Mean & 440.66 & 0.12 & 0.14 & 8.98 & 7.53 & 7.71 \\
Median & 158.45 & 0.11 & 0.13 & 9.08 & 7.43 & 8.13 \\
Maximum & 4305.69 & 0.27 & 0.27 & 10.87 & 10.74 & 10.65 \\
Minimum & 28.16 & 0.03 & 0.03 & 5.67 & 2.60 & -0.62 \\
Standard deviation & 738.60 & 0.05 & 0.05 & 1.10 & 1.46 & 1.85 \\
\hline
\end{tabular}

\section{RESULTS AND DISCUSSION}

\section{TECHNICAL EFFICIENCY}

The definition of technical efficiency measures is the fraction of the potential output produced by the firm. It highlights the relative value of the firm efficiency score in the range of 0 to 1 , which indicates that the value of 1 is efficient and that the value of less than 1 is inefficient. The firm is expected to maximise the output produced based on the available technology.
The technical efficiency results presented in Table 2 exhibits the distribution of technical efficiency scores by subsectors based on palm oil-based products. Out of 176 observations, 96 subsectors $(55.5 \%)$ are the food industries, while the remaining 80 subsectors (45.5\%) are non-food industries. From the table, the distribution of efficiency scores among the subsectors varies from 0 to 1 . The productive subsector accounted for $42.6 \%$, which is approximately 75 observations. The rest of the subsectors are inefficient registered of 57.6\% (101 observations), distributed in the range of 0.9-0.99 (43.1\%), 0.8-0.89 $(11.9 \%)$, and $0.7-0.79(2.3 \%)$.

TABLE 2. Technical efficiency by subsector

\begin{tabular}{|c|c|c|c|c|c|}
\hline \multirow[t]{2}{*}{ No. } & \multirow[t]{2}{*}{ Subsector } & \multicolumn{4}{|c|}{$\begin{array}{l}\text { Efficiency score } \\
\text { (BCC-VRS model) }\end{array}$} \\
\hline & & $0.7-0.79$ & $0.8-0.89$ & $0.9-0.99$ & 1.00 \\
\hline 1. & Manufacture of crude palm oil & & & 13 & 3 \\
\hline 2. & Manufacture of refined palm oil & & & 1 & 15 \\
\hline 3. & Manufacture of palm kernel oil & & & 9 & 8 \\
\hline 4. & $\begin{array}{l}\text { Manufacture of ice cream and other } \\
\text { edible ice }\end{array}$ & & 2 & 7 & 7 \\
\hline 5. & $\begin{array}{l}\text { Manufacture of condensed, powdered, evaporated milk } \\
\text { and other dairy products }\end{array}$ & & 1 & 13 & 2 \\
\hline \multirow[t]{2}{*}{6.} & Manufacture of other food products & & 3 & 9 & 3 \\
\hline & $\begin{array}{l}\text { Total subsectors of food palm oil products-based } \\
\text { industry }\end{array}$ & - & $\begin{array}{c}6 \\
(3.4)\end{array}$ & $\begin{array}{c}52 \\
(29.5)\end{array}$ & $\begin{array}{c}38 \\
(21.6)\end{array}$ \\
\hline 7. & $\begin{array}{l}\text { Manufacture of liquefied, compressed inorganic } \\
\text { industrial and medical gases }\end{array}$ & & & & 16 \\
\hline 8. & $\begin{array}{l}\text { Manufacture of basic organic chemical, inorganic } \\
\text { compound, and other basic chemicals }\end{array}$ & 1 & 8 & 6 & \\
\hline 9. & $\begin{array}{l}\text { Manufacture of soap and detergents, cleaning and } \\
\text { polishing preparations }\end{array}$ & & & 7 & 9 \\
\hline 10. & $\begin{array}{l}\text { Manufacture of medicinally active substances and } \\
\text { medicaments }\end{array}$ & & & 4 & 12 \\
\hline 11. & $\begin{array}{l}\text { Manufacture of biotech pharmaceuticals, other } \\
\text { pharmaceuticals, medicinal } \\
\text { chemical and botanical products }\end{array}$ & 3 & 7 & 7 & \\
\hline & $\begin{array}{l}\text { Total subsector of non-food palm oil products-based } \\
\text { industry }\end{array}$ & $\begin{array}{c}4 \\
(2.3)\end{array}$ & $\begin{array}{c}15 \\
(8.5)\end{array}$ & $\begin{array}{c}24 \\
(13.6)\end{array}$ & $\begin{array}{c}37 \\
(21.0)\end{array}$ \\
\hline & Total $(n=176)$ & $\begin{array}{c}4 \\
(2.3)\end{array}$ & $21(11.9)$ & $\begin{array}{c}76 \\
(43.1)\end{array}$ & $\begin{array}{c}75 \\
(42.6)\end{array}$ \\
\hline
\end{tabular}

Source: computed from the study

Note: The figure in the bracket is a percentage 


\section{RESULT OF HYPOTHESIS}

The selection of the model is verified based on the results of the hypothesis test. The first hypothesis is conducted on the Wald test (Green 2008) to assess the option between a pooled regression and a fixed-effect model. Table 3 discloses that the p-value of the Wald test for both models is below 0.05 . The result suggests that the null hypothesis is dismissed, and the alternative hypothesis specifies that the fixed-effects are an effective predictor. As a result, the fixed-effects model favoured in comparison to the pooled regression. The model does not consider heterogeneity across groups or time, which significantly affects the dependent variable. Also, the sampling distribution of the predictor in the regression of fixed-effects is normal in large samples.

TABLE 3. The hypotheses tests

\begin{tabular}{lcccccc}
\hline \multirow{2}{*}{ Hypothesis } & \multicolumn{5}{c}{ Model I } \\
\cline { 2 - 6 } & PLS & FE & RE & PLS & FE & RE \\
\hline F-Wald test (reject $H_{0}$ ) & - & $p<0.005$ & - & - & $p<0.005$ & - \\
Hausman test (reject $H_{0}$ ) & - & $p<0.005$ & - & - & $p<0.005$ & - \\
Durbin-Watson & 0.5437 & 2.1113 & 1.1597 & 0.5113 & 2.0964 & 0.8766 \\
\hline
\end{tabular}

Next, the subsequent test needed to perform the second hypothesis to decide whether it was random or fixed. At this point, the Hausman test determines the best estimator between the two models (Hausman 1978). As shown in Table 3, the p-value of the alternative hypothesis is statistically significant, which is $p<0.005$, resulting in the fixed-effects model is the better estimator as the model imposed time-independent effects for each entity.

With observation for both the time and individual (a cross-section unit), more information is available by performing efficient estimates. The model assumes unique attributes specifying that the fixed-effect model through cross-section units imposed time-invariant individual effects correlated with independent variables. The variations of individual effects address by different slopes and intercepts. Unobserved sources of individual heterogeneity vary across individuals, but the omitted variable bias is not permitted to differ over time.

The model parameters are fixed or non-random quantities across groups or periods. In many applications, the model refers to a group mean that is set fixed (nonrandom) instead of a random-effects model. The mean group is a random sample of the population (Ramsey \& Schafer 2002).

\section{THE FINDINGS}

Based on the hypothesis testing as discussed in the earlier section, the fixed-effects analysis is employed for both models I and II. Table 4 highlights the result of the covariance analysis, which reflects the multi-collinearity test among independent variables. From the table, this study has encountered a multi-collinearity problem for the variables ICT, training (TRN), and research and development (RND) variables. In general, the absolute value of the correlation coefficient is more than 0.8 among two or more predictors indicates the existence of multicollinearity (Neys 2017).

The result confirms that these variables have a strong correlation, resulting in a very low R-square value. Treatment could be either changing the variable measured or dropping the variable, which has a multi-collinearity problem. However, the variable's measurement could not simply change as data sourced from the DoSM database. Therefore, these variables (ICT, TRN and RND) have dropped from the model. 
TABLE 4. The multi-collinearity test

\begin{tabular}{cccccccc}
\hline Variable & TE & ICT & KL & TRN & RND & PRO & TEC \\
\hline TE & 1.000 & & & & & & \\
ICT & 0.041 & 1.000 & & & & & \\
KL & 0.040 & 0.897 & 1.000 & & & & \\
TRN & 0.025 & 0.946 & 0.950 & 1.000 & & & \\
RND & 0.050 & 0.886 & 0.821 & 0.881 & 1.000 & & \\
PRO & -0.089 & 0.159 & 0.245 & 0.206 & -0.063 & 1.000 & \\
TEC & -0.210 & 0.002 & -0.049 & -0.040 & -0.208 & 0.388 & 1.000 \\
\hline
\end{tabular}

Table 5 shows the results of model I and model II, respectively. The results of the effect on technical efficiency presented the main results of model I. Next, the findings of model II analyse the moderating effects of human capital contribution by occupational types according to the food and non-food industry of the manufacturing sector palm oil products-based. After solving the multi-collinearity problem, the R-square values for model I increased to 0.693 , implying that all the independent variables examined in this study contributed $69.3 \%$ to the technical efficiency scores. In model II, the interaction between the dummy variable, and the technical and supervisory group of labour is relatively small, approximately $16.0 \%$. However, in the case of dummy variables and professional labour, the value of R-squared is tiny since D*PRO is not statistically significant in affecting the technical efficiency of the food industry's.

The findings of the model I primary concern in this present study show the remaining variables that contribute to the technical efficiency are the capital-labour ratio (KL), the professional labour ratio (PRO) and the technical and supervisory labour ratio (TEC). All variables show the results are statistically significant at 0.05 levels of significance. The outcomes of technical and supervisory and professional labour are positively and significantly contribute to the technical efficiency scores' performance.
An increase of $1 \%$ in the variable TEC and PRO would increase the technical efficiency score by 0.200 and $0.281 \%$, respectively. The findings show that both skilled labour (professional, and technical and supervisory) are essential and significantly affect the production of the palm oil products-based manufacturing subsector. Past studies have shown that educated workers correlate with firm technical efficiency (Andersson \& Stone 2017; Fahmy et al. 2019). The finding is parallel to the result obtained by Andersson and Stone (2017) stated firms with a larger proportion of high skilled employees have a smaller distance to the production possibilities frontier, whereby it is an efficient firm's position.

In contrast, the capital-labour ratio though significant, but has negatively affected the subsectors' efficiency scores. The finding expects that technology, including machinery, and equipment, is not fully equipped, thereby, contributing to the adverse effect of the technical efficiency scores. Such a prior study obtained technology has a positive relationship with technical efficiency (Ismail \& Sulaiman 2007); however, it opposed the finding observed by Fahmy et al. (2020, 2019). The excess capacity of capital leads to a decline in industry efficiency as the technology requires more skilled workers to operate more advanced machinery and equipment. 
TABLE 5. The results

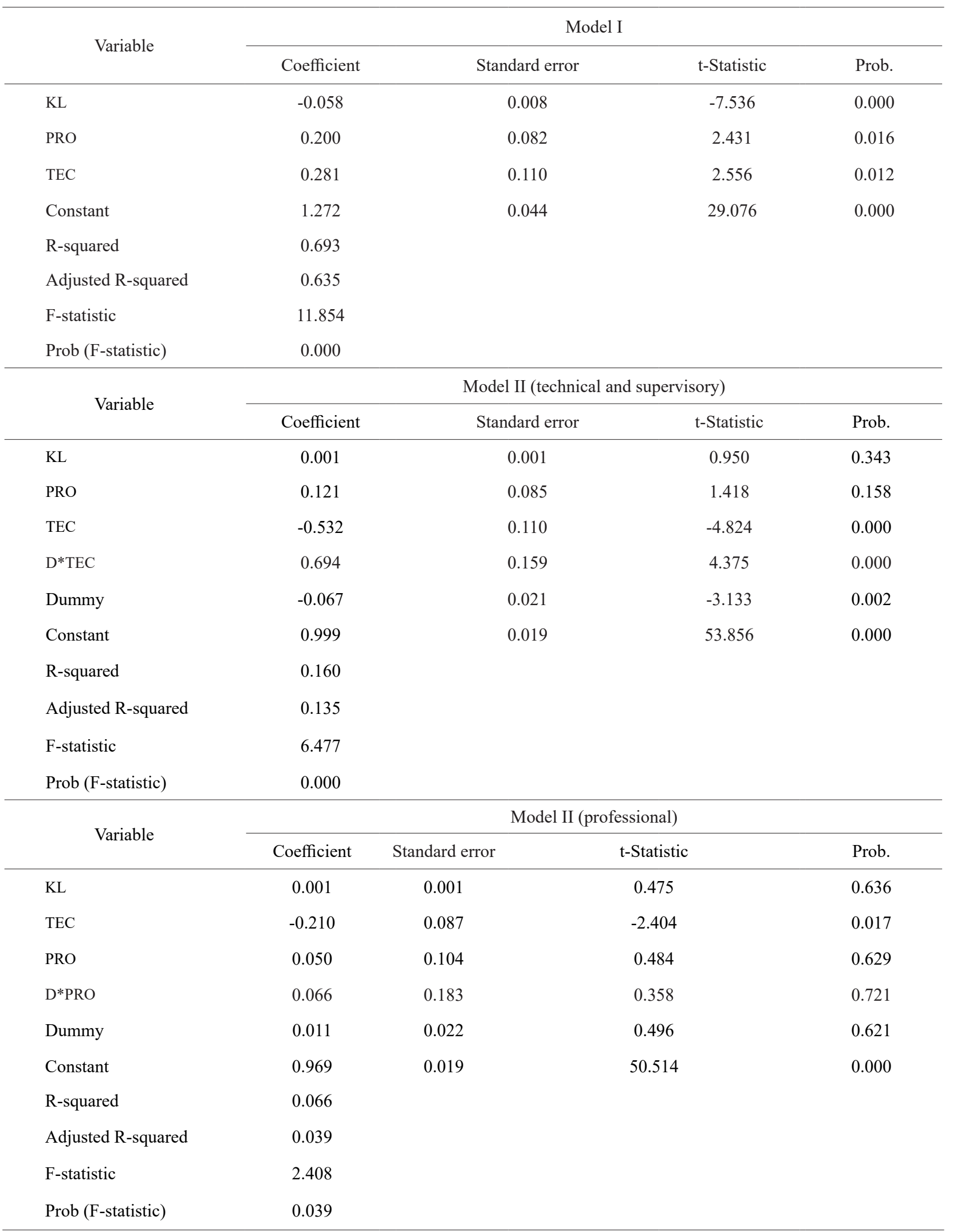


In this study, model II is conducted by generating two intercept values: a constant variable $(\alpha)$, which is similar as for in model I, and the Dummy variable is the constant or intercept value of model II only for the food industry. For model II, in the case of D*TEC, the intercept value is negative, showing the overall mean of technical efficiency of the food industry is lower than the mean (intercept value) of the initial model. However, this is the opposite in the case of D*PRO. Therefore, both interactions D*TEC and $\mathrm{D} * \mathrm{PRO}$ present the positive value of the slopes.

Also, the results of Model II take into account the moderating effects of skilled labour on the industry type. The finding shows technical and supervisory labour in the food industry is statistically significant at a 0.01 level of significance. A $1 \%$ increase in that group of occupations will increase technical efficiency of the palm oil productsbased food industry by $0.694 \%$. The result implies that this labour (technical and supervisory worker) relatively affects the food industry's technical efficiency higher than the non-food industry. The finding draws attention that this type of skilled labour is comparatively more required, perhaps due to the nature of the industry in the production of food goods, beverages, and other food processing.

The food and beverages industry is considered labour-intensive industries (including high and low skilled workers) as almost all of the firm's ownerships are small and medium-sized enterprises (SMEs). As a result, the subsector recorded the largest growth contributing up to $11.0 \%$ in 2017. Although it experienced slower growth of approximately $3.6 \%$ due to reduced beverage production, the industry contributed $22.0 \%$ to the value-added of the manufacturing sector in 2018 (SMEs 2018/2019).

In contrast, professional labour is not statistically significant though it had a positive sign. It is worth mentioning that the quality of labour associated with skilled labour as proposed in human capital theory is a focal point since it positively contributes to productivity (Becker 1994).

\section{CONCLUSION}

Based on the research objectives, the calculation of technical efficiency and the analysis of the technical efficiency determinants, this study concludes with several findings specifically for the manufacturing subsector of palm oil products-based. First, most of the palm oil products-based subsectors are not operating at an efficient level. Despite achieving an efficiency level, the majority of them have low technical efficiency scores. These industries still have more rooms to improve efficiency by managing inputs used in the production side to be utilised efficiently. However, it involves several aspects, including the structure of firm's organisation, the infrastructure, the technology equipped, and human resources.

Second, skilled labour is one of the major determinants that contribute to the technical efficiency scores. The contribution of skilled workers (technical, supervisory and professional) is indisputably, and directly affecting technical efficiency. The contribution of the capitallabour ratio is, however, significant, but it is detrimental to efficiency. It is not an exaggeration to say that perhaps capital is underutilised, and the industry's characteristics are still relying on labour (both skilled and low skilled) in the production process. Third, the moderating effects between technical and supervisory workers and the food industry show that this labour group is relatively needed in the food manufacturing sector due to that industry's characteristics.

One of the risks of relying is difficulty in obtaining skilled workers. Without more skilled workers, the economy will find it more challenging to move up the value chain and not attract large capital investments. Unfortunately, the country suffers from a shortage of skilled workers, weak productivity growth stemming from a lack of creativity and innovation in the workforce, and an over-reliance on unskilled and low-wage migrant workers.

The study's findings show that palm oil productsbased are growing and need support from downstream industries that supply oil palm for the upstream activities. Upstream activities (such as fruit bunches production in the fields, processing of fresh fruit bunch, crude palm oil, palm kernel oil, and refined palm oil) expand from downstream production activities that firmly establish a supply chain for the oil palm based-products industry. These include palm oil refining, edible oil and fats, palmbased food, and basic oleo-chemicals products. Moreover, palm oil products are also used in biodiesel fuel and the primary feedstock for the oleo-chemicals industry.

In conclusion, the palm oil-based products are becoming a worldwide market in the 21 st century as it is diversified in food and non-food products. Thus, the findings underscored that efficiency and key variables were the main concerns of the present study, as Malaysia has become the leading palm oil hub of trade and knowledge. Moreover, the relationship between oil palm upstream and downstream industries requires adequate support to enhance innovation and research and development in palm 
oil to sustain exports, employment, and production at the farm level and improve the farmer's livelihoods.

Due to the data constraint, which is available at the industry level, this study suggests future research to take the initiative by measuring the efficiency and determinants of the industrial palm oil products based on a firm-level basis. The results would be more exciting and useful in such a way to provide a better understanding of the performance, productivity and competitiveness of the palm oil products-based industry at the firm level.

\section{ACKNOWLEDGEMENTS}

This article is based on a research project funded by the Grant of Endowment Chair MPOB-UKM (EP-2015-065).

\section{REFERENCES}

Andersson, M. \& Stone, T-A. 2017. Global sourcing and technical efficiency: a firm-level study on the ICT industry in Sweden. Journal of Business Economics and Management 18(5): 877-896

Amiruddin, M.N., Ab Rahman, A.K. \& Shariff, F. 2005. Market potential and challenges for the Malaysian palm oil industry in facing competition from other vegetable oils. Oil Palm Industry Economic Journal 5(1): 17-27.

Banker, R.D., Charnes, A. \& Cooper, W.W. 1984. Some models for estimating technical and scale inefficiencies in data envelopment analysis. Management Science 30(9): 10781092.

Becker, G. 1994. Human capital: A Theoretical and Empirical Analysis, with Special Reference to Education. New York: Columbia University Press.

Charnes, A.C., Cooper, W.W. \& Rhodes, E. 1978. Measuring the efficiency of decision-making units. European Journal of Operational Research 2(6): 429-444.

Coelli, T.J. 1996. A Guide to Frontier Version 4.1: A Computer Program for Stochastic Frontier Production and Cost Function Estimation (No.7/96). New South Wales: Australia.

Coelli, T.J. \& Battese, G.E. 1996. Identification of factors which influence the technical inefficiency of Indian farmers. Australian Journal of Agricultural Economics 40: 103-128.

Coelli, T.J., Rao, D.S.P., O’Donnell, C.J. \& Battese, G.E. 2005. An Introduction to Efficiency and Productivity Analysis. 2nd ed. New York, U.S: Springer.

Cooper, W.W., Seiford, L.M. \& Zhu, J. 2011. Data envelopment analysis: History, models, and interpretations. In Handbook on Data Envelopment Analysis, edited by Cooper, W.W., Seiford, L.M. \& Zhu, J. New York, U.S.: Springer. pp. 1-39.

Department of Statistics Malaysia (DoSM). 2013. Industrial Manufacturing Survey. Putrajaya: Department of Statistics Malaysia.
European Commission. 2009. European Competitiveness Report 2008. https://ec.europa.eu/growth/content/europeancompetitiveness-report-2008-0_en.

Fahmy-Abdullah, M., Lai, W.S., Sulaiman, N. \& Abd Rahim, M.H.I. 2020. Measuring inefficiency in the rubber manufacturing industry. International Journal of Economics, Management and Accounting 28(1): 79-96.

Fahmy-Abdullah, M., Lai, W.S. \& Ridzuan, S. 2019. Analisis penyampulan data (DEA) dua peringkat dalam mengenal pasti faktor penentu kecekapan teknik firma pembuatan pengangkutan. Sains Malaysiana 48(4): 901-908.

Fahmy-Abdullah, M., Ismail, R., Sulaiman, N. \& Abdul Talib, B. 2017. Technical efficiency in transport manufacturing firms: Evidence from Malaysia. Asian Academy of Management Journal 22(1): 57-77.

Farrell, M.J. 1957. The measurement of productive efficiency. Journal of Royal Statistical Society 120: 253-290.

Greene, W.H. 2008. Econometric Analysis. 6th ed. Upper Saddle River, N.J.: Prentice Hall.

Hausman, J.A. 1978. Specification tests in econometrics. Econometrica 46(6): 1251-1271.

Ismail, R. \& Sulaiman, N. 2007. Technical efficiency in Malay manufacturing firms. International Journal of Business and Society 8: 47-62.

Ismail, R. 2009. Technical efficiency, technical change and demand for skills in Malaysian food-based industry. European Journal of Social Sciences 9(3): 504-515.

Jajri, I. \& Ismail, R. 2006. Technical Efficiency, Technological Change and Total Factor Productivity Growth in Malaysian Manufacturing Sector. http://mpra.ub.uni-muenchen. de/1956/1/MPRA_paper_1956.pdf.

Kalirajan, K.P. \& Tse, Y.K. 1989. Technical efficiency measures for the Malaysian food manufacturing industry. The Developing Economy 27(2): 174-184.

Latruffe, L. 2010. Competitiveness, Productivity and Efficiency in the Agricultural and Agri-food Sectors in OECD Food, Agriculture and Fisheries. Paper No.30, Paris: OECD Publishing.

Mad Nasir, S., Yodfiatfinda, Radam, A. \& Yusop, Z. 2013. Partial productivity and technical efficiency of small and medium enterprises in the Malaysian food processing industry. Pertanika Journal of Social Science and Humanities 21: 17-30.

Mahadevan, R. 2001. Assessing the output and productivity growth of Malaysia's manufacturing sector. Journal of Asian Economics 12(4): 587-597.

MASCO. 2013. Malaysia Standard Classification of Occupations. Putrajaya: Department of Statistics Malaysia.

Mohd Noor, Z. \& Ismail, R. 2007. Analisis kecekapan teknik dalam industri skel kecil dan sederhana di Malaysia International Journal of Management Studies 14(1): 199. 218. 
MPIC. 2017. Ministry of Plantation Industries and Commodities. http://www.kppk.gov.my/mpic/index.php/en/. Assessed on 31 May 2017.

MPOB. 2020. Malaysian Palm Oil Board official portal Economics and Industry Development-Division. http://bepi mpob.gov.my/index.php/en/?option=com_content\&view=art icle\&id $=906 \&$ Itemid $=138$. Accessed on 10 July 2020 .

MPOB. 2017. Malaysian Palm Oil Board official portal. Oil Palm Production Statistics. http://www.mpob.gov.my/ Assessed on 31 May 2017.

MSIC. 2000. Malaysian Standard Industrial Classification. Department of Statistics Malaysia. Kuala Lumpur: Percetakan Nasional Malaysia Berhad.

MSIC. 2008. Malaysian Standard Industrial Classification. Department of Statistics Malaysia. Kuala Lumpur: Percetakan Nasional Malaysia Berhad.

Neys, J. 2017. Multi-collinearity. In The SAGE Encyclopedia of Communication Research Methods, edited by Allen, M. California, U.S.: SAGE Publications.

Porter, M.E. 1990. The Competitive Advantage of Nations. New York: The Free Press.

Ramsey, F. \& Schafer, D. 2002. The Statistical Sleuth: A Course in Methods of Data Analysis. 2nd ed. London: Duxbury Press.

Seiford, L.M. 1996. Data envelopment analysis: The evolution and state of the art. Journal of Productivity Analysis 7(2/3): 99-137.

Shahbandeh, M. 2020. Vegetable Oils: Global Consumption by Oil Type 2013/14-019/2020. https://www.statista.com/ statistics/263937/vegetable-oils-global-consumption/. Accessed on 10 July 2020

SME Annual Report 2018/2019. Entrepreneurship Drives SMEs. Kuala Lumpur: SME Corporation Malaysia.

Sulaiman, N. \& Ismail, R. 2007. Kecekapan teknik firma usahawan Melayu dalam sektor perkhidmatan. Jurnal Teknologi 46(E): 113-130.

Yodfiatfinda, Mad Nasir, S., Mohamed, Z.A., Yusop, Z. \& Radam, A. 2012. The empirical evaluation of productivity growth and efficiency of LSEs in the Malaysian food processing industry. International Food Research Journal 19(1): 287295.

Zakaria, K., Mohamed Salleh, K. \& Balu, N. 2017. The effect of soybean oil price changes on palm oil demand in China. Oil Palm Industry Economic Journal 17(1): 1-7.

Center for Sustainable and Inclusive Development Faculty of Economics and Management

Universiti Kebangsaan Malaysia 43600 UKM Bangi, Selangor Darul Ehsan Malaysia

*Corresponding author; email: rasiahs@ukm.edu.my

Received: 7 January 2020

Accepted: 19 November 2020 
APPENDIX 1. Description of industry according to palm oil products-based manufacturing subsector

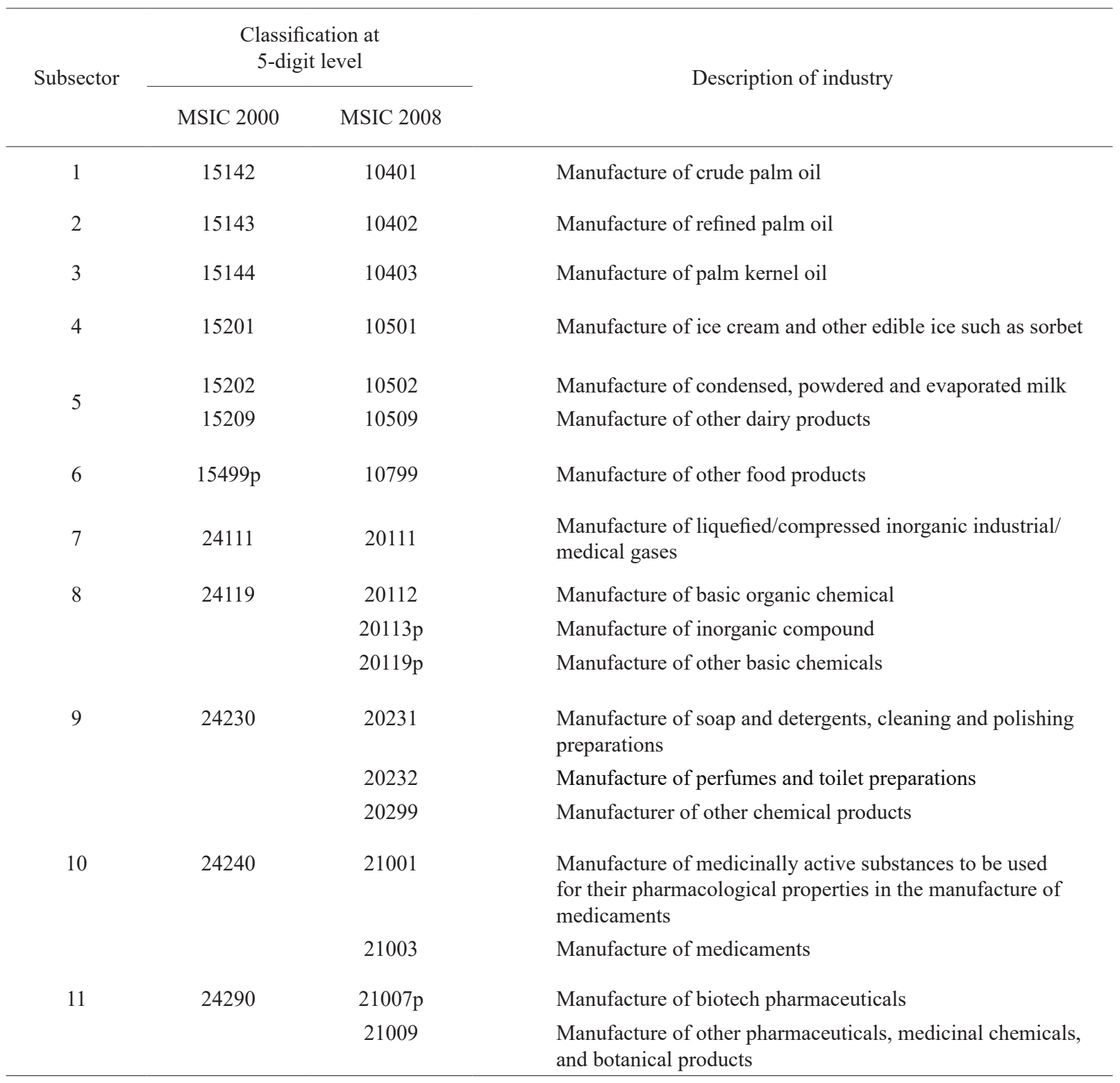

